\title{
PERBEDAAN EFEK EKSTRAK BAWANG MERAH TERHADAP PERTUMBUHAN Streptococcus mutans DARI KARIES DAN Streptococcus mutans (ATCC ${ }^{\circledR}$ 35668 $^{\mathrm{TM}}$ )
}

\author{
Minasari*, Sri Amelia**, Nevi Tinambunan*** \\ * Departemen Biologi Oral Fakultas Kedokteran Gigi, ** Departemen Mikrobiologi Fakultas Kedokteran \\ *** Mahasiswa Fakultas Kedokteran Gigi \\ Universitas Sumatera Utara
}

\begin{abstract}
Abstrak
Bawang merah merupakan tanaman herbal yang biasa digunakan sebagai bumbu masakan yang memiliki efek antibakteri karena adanya kandungan alkaloid, saponin, dan flavonoid. Alkaloid berfungsi dalam menghambat sintesis protein dan asam nukleat, saponin berperan dalam merusak permeabilitas membran sel, dan flavonoid berfungsi dalam menghancurkan dinding sel Streptococcus mutans. Streptococcus mutans adalah bakteri dominan terjadinya karies. Penelitian ini bertujuan untuk mengetahui efek ekstrak bawang merah terhadap pertumbuhan Streptococcus mutans dari karies dan Streptococcus mutans (ATCC ${ }^{\circledR} 35668^{\mathrm{TM}}$ ), serta untuk mengetahui perbedaan efek ekstrak bawang merah terhadap kedua jenis bakteri tersebut. Penelitian ini merupakan penelitian eksperimental laboratoris dengan rancangan posttest control group design. Sampel yang digunakan adalah biakan Streptococcus mutans yang diisolasi dari pasien karies dan Streptococcus mutans $\left(\mathrm{ATCC}^{\circledR} 35668^{\mathrm{TM}}\right.$ ). Ekstrak bawang merah dilakukan dengan metode dilusi untuk mendapatkan berbagai konsentrasi ekstrak 80\%, 40\%, 20\%, 10\%, 5\%, 2,5\%, dan 1,25\% kemudian ditambahkan suspensi bakteri pada setiap konsentrasi. Analisis data yang digunakan adalah uji deskriptif frekuensi yaitu median untuk mendapatkan nilai tengah dari konsentrasi KHM dan KBM yang dilakukan dengan tiga kali pengulangan dan uji statistik Mann Whitney yang digunakan untuk mencari apakah terdapat perbedaan yang signifikan antara konsentrasi KHM dan KBM bakteri Streptocccus mutans dari karies dan Streptococcus mutans $\left(\mathrm{ATCC}^{\circledR} 35668^{\mathrm{TM}}\right.$ ). Hasil penelitian ini diperoleh konsentrasi KHM dan KBM dari ekstrak bawang merah terhadap pertumbuhan bakteri Streptococcus mutans yang diisolasi dari pasien karies masing-masing $40 \%$ dan $80 \%$. Adapun nilai KHM dan KBM dari ekstrak bawang merah terhadap pertumbuhan Streptococcus mutans $\left(\mathrm{ATCC}^{\circledR} 35668^{\mathrm{TM}}\right.$ ) masing-masing $20 \%$ dan $40 \%$. Hasil uji Mann Whitney menunjukkan tidak terdapat perbedaan efek yang signifikan ( $>00,05)$ antara nilai KHM dan KBM dari ekstrak bawang merah terhadap kedua jenis Streptococcus mutans. Berdasarkan hasil penelitian ini, dapat disimpulkan bahwa ekstrak bawang merah memiliki efektivitas terhadap pertumbuhan Streptococcus mutans dari karies dan Streptococcus mutans $\left(\right.$ ATCC $^{\circledR} 35668^{\mathrm{TM}}$ ).
\end{abstract}

Kata Kunci : bawang merah, karies, antibakteri, KHM, KBM, Streptococcus mutans

\section{PENDAHULUAN}

Karies merupakan suatu penyakit jaringan keras gigi pada enamel, dentin, dan sementum yang disebabkan aktivitas jasad renik dalam suatu karbohidrat yang diragikan. ${ }^{1}$ Survei Kesehatan Rumah Tangga (SKRT) tahun 2009 menunjukkan bahwa penduduk Indonesia yang menderita karies gigi sebesar 73\%. Data Kementerian Kesehatan Republik Indonesia (Kemenkes RI) juga menunjukkan bahwa angka keluhan sakit oleh karena karies cukup tinggi yaitu sebanyak $1,3 \%$ atau 2620 penduduk Indonesia perbulan. $^{2}$ Berdasarkan Riset Kesehatan Dasar (Riskesdas) tahun 2013 secara keseluruhan nilai Indeks DMF-T Indonesia sebesar 4,6 yang berarti kerusakan gigi penduduk Indonesia 460 buah gigi per 100 orang.
Bakteri yang berperan dalam pembentukan karies yaitu Streptococcus mutans,Streptococcus salivarius, Streptococcus sanguis, Lactobacillus acidophilus, Lactobacillus casei, Actynomyces viscosus, Actynomyces naeslundii tetapi yang paling dominan adalah Streptococcus mutans. ${ }^{3}$ Interaksi Streptococcus mutans pada permukaan gigi menyebabkan proses demineralisasi enamel. Bila proses demineralisasi ini terus berulang dengan cepat dan tidak seimbang dengan remineralisasi maka dapat terjadi karies. ${ }^{4}$

Upaya untuk mengendalikan Streptococcus mutans yaitu dengan menggunakan bahan yang bersifat antibakteri. Salah satu tanaman yang juga mempunyai potensi antibakterial terhadap Streptococcus mutans adalah bawang merah. ${ }^{5,6}$

Bawang merah merupakan salah satu komoditas sayuran yang sering digunakan sebagai 
bumbu dapur sehari-hari dan penyedap berbagai masakan. $^{7}$ Senyawa aktif yang terkandung dalam bawang merah yaitu quercetin, isorhamnetin, allisin, alliin, diallyl monosulfide, diallyl disulfide, diallyl trisulfide, diallyl tetrasulfide quercetin glucoside, isorhamnetin diglucoside. ${ }^{8}$ Zat yang mempunyai efek antibakteri dari senyawa aktif tersebut adalah alkaloid, saponin, dan flavonoid. Alkaloid berfungsi dalam menghambat sintesis protein dan asam nukleat, saponin berperan dalam merusak permeabilitas membran sel, dan flavonoid berfungsi dalam menghancurkan dinding sel Streptococcus mutans. ${ }^{6}$

Beberapa penelitian telah dilaporkan mengenai aktivitas biologis dari bawang merah, antara lain sebagai antidiabetes, antihipertensi, antioksidan, antialergi, antimycobacterium, antiparasit. Selain itu ada juga penelitian yang mengemukakan bahwa bawang merah mempunyai efek antijamur, antipiretik, antiinflamasi, antikanker, dan antithrombosis. ${ }^{9}$

Penelitian Jahangirnezhad, Amin, Montazeri dan Eftekhari (2012) di Afrika mengemukakan bahwa ekstrak bawang merah memiliki daya aktivitas antimikroba terhadap Streptococcus mutans. ${ }^{10}$ Mahmoudi, Zare, Shadfar dan Ehsani (2009) di Iran juga mengemukakan ekstrak bawang merah mempunyai karakterisitik daya antimikroba. $^{11}$ Penelitian Amin, Montazeri, Mashhadizadeh dan Sheikh (2011) di Iran juga mengemukakan bahwa ekstrak bawang merah dapat menghambat pertumbuhan bakteri yang tetap stabil dalam pH dan suhu yang berbeda. ${ }^{12}$

Penelitian Amin dan Kapadnis (2005) di India menyatakan bahwa ekstrak bawang merah memiliki daya antimikrobial pada bakteri gram positive dan negative. ${ }^{13}$ Hasil yang sama juga ditunjukkan pada penelitian Ambarwaty (2014) di Surakarta, Indonesia yang mengemukakan adanya pengaruh pemberian jus bawang merah terhadap pertumbuhan bakteri Streptococcus mutans $\left(\text { ATCC }^{\circledR} 25175^{\mathrm{TM}}\right)^{6}$

Penelitian

Rattanachaikunsopon

dan Phumkhachorn (2009) di Thailand mengemukakan bahwa ekstrak bawang merah memiliki karakteristik daya antimikroba terhadap beberapa bakteri yaitu Esherichia coli, Bacillus cereus, Vibrio cholerae dan Salmonella enterica. ${ }^{14}$ Sejalan dengan itu penelitian Akeel, Alseikh, Mateen, Syed, Janardhan dan Gupta (2014) di Arab Saudi juga mengemukakan hal yang sama, salah satunya untuk bakteri patogen di dalam rongga mulut. ${ }^{15}$

Dari penelitian terdahulu, dapat diketahui bahwa ekstrak bawang merah mempunyai efek antibakteri terhadap Streptococcus mutans. Namun belum terdapat penelitian yang menggunakan Streptococcus mutans yang diisolasi dari pasien karies dan Streptococcus mutans yang dihasilkan oleh American Type Culture Collection, yaitu Streptococcus mutans $\left(\right.$ ATCC $^{\circledR} 35668^{\mathrm{TM}}$ ). Selain itu, belum terdapat penelitian yang membandingkan tentang strain bakteri yang diisolasi dari karies dan biakan murni.Berdasarkan uraian diatas, penulis tertarik untuk melakukan penelitian untuk mengetahui berapa konsentrasi KHM dan KBM dari ekstrak bawang merah terhadap pertumbuhan Streptococcus mutans dari karies dan Streptococcus mutans $\left(\mathrm{ATCC}^{\circledR} 35668^{\mathrm{TM}}\right.$ ), serta untuk mengetahui apakah terdapat perbedaan efek ekstrak bawang merah terhadap pertumbuhan Streptococcus mutans dari karies dan Streptococcus mutans (ATCC $^{\circledR}$ $35668^{\mathrm{TM}}$ ).

\section{BAHAN DAN METODE}

Penelitian ini merupakan penelitian eksperimental laboratoris dengan rancangan posttest control group design. Sampel penelitian ini adalah biakan Streptococcus mutans yang diisolasi dari gigi karies, serta biakan Streptococcus mutans (ATCC ${ }^{\circledR} 35668^{\mathrm{TM}}$ ) dari Laboratorium Mikrobiologi Fakultas Kedokteran UGM. Adapun jumlah sampel masing-masing sebanyak satu biakan Streptococcus mutans dari karies dan (ATCC $^{\circledR}$ $35668^{\mathrm{TM}}$ ).

Pengujian ekstrak bawang merah terhadap Streptococcus mutans dilakukan dengan metode dilusi untuk mendapatkan nilai KHM dan KBM dari beberapa konsentrasi yang dimasukkan kedalam tabung reaksi dengan larutan ekstrak bawang merah konsentrasi $80 \%$, $40 \%, 20 \%, 10 \%, 5 \%, 2,5 \%, 1,25 \%$ serta dua buah kontrol, yaitu Formaldehyd $40 \%$ sebagai kontrol positif dan akuabidest sebagai kontrol negatif. Kemudian ditambahkan suspensi Streptococcus mutans kedalam masing-masing tabung reaksi dan divortex hingga campuran menjadi homogen. Campuran kemudian dimasukkan kedalam inkubator pada suhu $37^{\circ} \mathrm{C}$ selama 24 jam, dan dilakukan pengamatan apakah terbentuk endapan atau tidak. Tabung dengan konsentrasi terendah yang tidak terbentuk endapan menunjukkan efek bakteriostatis dan konsentrasi tersebut disebut nilai KHM. Semua tabung yang tidak terbentuk endapan kemudian dilakukan subkultur pada media Blood Agar yang tersedia dipiring petri dan diinkubasi dalam inkubator suhu $37^{\circ} \mathrm{C}$ selama 24 jam. Media Blood Agar dari piring petri dengan konsentrasi terendah yang tidak terbentuk pertumbuhan koloni menunjukkan efek bakterisidal dan konsentrasi tersebut disebut nilai KBM.

Seluruh prosedur ini dilakukan pengulangan sebanyak tiga kali untuk mencegah terjadinya bias. Setelah nilai $\mathrm{KHM}$ dan $\mathrm{KBM}$ dari masing-masing pengujian diperoleh, dilakukan perhitungan secara statistik menggunakan median untuk mendapatkan nilai KHM dan KBM dari ketiga pengulangan. Kemudian untuk menguji apakah terdapat perbedaan yang signifikan antara pertumbuhan Streptococcus mutans dari karies dan Streptococcus mutans $\left(\mathrm{ATCC}^{\circledR} 35668^{\mathrm{TM}}\right.$ ) digunakan uji Mann Whitney.

HASIL

Tabel 1. Median Nilai KHM dan KBM Dari Ekstrak Bawang Merah Terhadap Pertumbuhan Bakteri Streptococcus mutans dari karies

\begin{tabular}{ccc}
\hline Nilai & N & Med \\
\hline Kadar Hambat Minimum (KHM) & 3 & $40 \%$ \\
Kadar Bunuh Minimum (KBM) & 3 & $80 \%$ \\
\hline
\end{tabular}

Keterangan :

$\mathrm{N}$ = banyaknya pengulangan

Med = nilai tengah 
Tabel 2. Median Nilai KHM dan KBM Dari Ekstrak Bawang Merah Terhadap Pertumbuhan Bakteri Streptococcus mutans $\left(\mathrm{ATCC}^{\circledR} 35668^{\mathrm{TM}}\right.$ )

\begin{tabular}{ccc} 
Streptococcus mutans (ATCC & 35668 & \\
\hline Nilai & N & Med \\
\hline Kadar Hambat Minimum (KHM) & 3 & $20 \%$ \\
Kadar Bunuh Minimum (KBM) & 3 & $40 \%$ \\
\hline
\end{tabular}

\section{Keterangan :}

$\mathrm{N}$ = banyaknya pengulangan

Med $=$ nilai tengah

Tabel 3. Perbedaan Median Nilai KHM dan KBM dari Ekstrak Bawang Merah terhadap Pertumbuhan Streptococcus mutans dari karies dan Streptococcus mutans $\left(\mathrm{ATCC}^{\circledR} 35668^{\mathrm{TM}}\right.$ )

\begin{tabular}{ccccc}
\hline Nilai & $\begin{array}{c}\text { Streptococcus } \\
\text { mutans }\end{array}$ & N & Med & P \\
\hline KHM & Karies $^{\text {TM }}$ & 3 & $40 \%$ & 0,3 \\
& ATCC $^{\circledR} 35668^{\mathrm{TM}}$ & 3 & $20 \%$ & 17 \\
\hline KBM & Karies $^{\circledR}$ & 3 & $80 \%$ & 0,3 \\
\hline
\end{tabular}

Keterangan :

$\mathrm{N} \quad=$ banyaknya pengulangan

Med = nilai tengah

$\mathrm{p} \quad=$ nilai signifikansi, tidak terdapat

perbedaan yang signifikan

$(\mathrm{p}>0,05)$

\section{PEMBAHASAN}

Bawang merah merupakan salah satu komoditas sayuran yang sering digunakan sebagai bumbu dapur sehari-hari dan penyedap berbagai masakan. ${ }^{7}$ Senyawa aktif yang terkandung dalam bawang merah yaitu saponin, flavonoid, quercetin, isorhamnetin, allisin, alliin, diallyl monosulfide, diallyl disulfide, quercetin glucoside, isorhamnetin diglucoside. ${ }^{8}$ Zat yang mempunyai efek antibakteri dari senyawa aktif tersebut adalah alkaloid, saponin, dan flavonoid. ${ }^{6}$

Hasil penelitian menunjukkan adanya efek bakteriostatis dan bakterisidal dari berbagai konsentrasi ekstrak bawang merah terhadap pertumbuhan Streptococcus mutans dari karies dan Streptococcus mutans $\left(\mathrm{ATCC}^{\circledR} 35668^{\mathrm{TM}}\right.$ ). Pada Streptococcus mutans yang diisolasi dari pasien karies, didapati nilai KHM terdapat pada konsentrasi $40 \%$ dan nilai $\mathrm{KBM}$ terdapat pada konsentrasi $80 \%$. Sedangkan pada Streptococcus mutans $\left(\mathrm{ATCC}^{\circledR} 35668^{\mathrm{TM}}\right.$ ), nilai $\mathrm{KHM}$ terdapat pada konsentrasi $20 \%$ dan nilai KBM $40 \%$.

Pada penelitian ini, peneliti membandingkan nilai KHM dan KBM dari ekstrak bawang merah terhadap pertumbuhan Streptococcus mutans yang diisolasi dari pasien karies dengan Streptococcus mutans (ATCC $^{\circledR}$ $35668^{\mathrm{TM}}$ ). Hasil uji Mann Whitney diperoleh (Tabel 3) menunjukkan tidak adanya perbedaan yang signifikan ( $>0,05$ ) antara nilai KHM dan KBM dari ekstrak bawang merah terhadap pertumbuhan Streptococcus mutans yang diisolasi dari karies dan Streptococcus mutans (ATCC $^{\circledR}$ $35668^{\mathrm{TM}}$ ). Salah satu penyebab tidak terdapat perbedaan yang signifikan karena Streptococcus mutans yang diisolasi dari karies dan Streptococcus mutans (ATCC $^{\circledR}$
$35668^{\mathrm{TM}}$ ) berasal dari serotipe yang sama. Persamaan serotipe menggambarkan karakterisitik struktur sel yang sama saat bereaksi dengan zat antibakteri, sehingga efek bakteriostatik dan bakterisidal Streptococcus mutans yang diisolasi dari karies menunjukkan konsentrasi yang hampir sama yaitu $40 \%$ dan $80 \%$ dengan Streptococcus mutans $\left(\right.$ ATCC $^{\circledR} 35668^{\mathrm{TM}}$ ) yaitu $20 \%$ dan $40 \%$.

Selain Streptococcus mutans, ekstrak bawang merah juga memiliki karakterisitik antimikrobial terhadap bakteri lain. Berdasarkan peneliti-peneliti terdahulu membuktikan adanya kemampuan daya antibakteri ekstrak bawang merah seperti yang dilakukan oleh Rattanachaikunsopon dan Phumkhachorn (2009) di Thailand yaitu terhadap bakteri Esherichia coli, Bacillus cereus, Vibrio cholerae dan Salmonella enterica. ${ }^{14}$ Sejalan dengan itu penelitian Akeel, Alseikh, Mateen, Syed, Janardhan dan Gupta (2014) di Arab Saudi juga mengemukakan hal yang sama, untuk bakteri patogen di dalam rongga mulut yaitu Staphylococcus aureus. ${ }^{15}$ Penelitian Amin, Montazeri, Mashhadizadeh dan Sheikh (2011) di Iran juga mengemukakan bahwa ekstrak bawang merah dapat menghambat pertumbuhan bakteri Bacillus subtilis, Trichophyton rubrum, Aspergillus niger, Cryptococcus humicolus. ${ }^{12}$ Penelitian Amin dan Kapadnis (2005) di India juga menyatakan bahwa ekstrak bawang merah memiliki daya antimikrobial terhadap bakteri Listeria monocytogenes, Salmonella typhi, Serratia marcescens, dan Shigella sp. ${ }^{13}$

Adapun faktor yang memengaruhi kemampuan ekstrak bawang merah dalam bersifat bakteriostatis dan bakterisidal yaitu adanya senyawa aktif seperti alkaloid, saponin, dan flavonoid. ${ }^{9}$ Senyawa kimia yang memiliki aktivitas antibakteri dalam ekstrak bawang merah yaitu alkaloid. Kemampuan senyawa alkaloid sebagai antibakteri yaitu dengan memanfaatkan sifat reaktif gugus basa yang dimiliki senyawa tersebut. Gugus basa pada alkaloid apabila mengalami kontak dengan bakteri akan bereaksi dengan senyawa-senyawa asam amino yang menyusun dinding sel dan DNA bakteri yang merupakan penyusun utama inti sel. Dengan terganggunya DNA maka sintesis protein dan asam nukleat dalam sel akan terganggu. ${ }^{16}$ Reaksi ini mengakibatkan terjadinya perubahan struktur dan susunan asam amino karena sebagian besar asam amino telah bereaksi dengan gugus basa dari senyawa alkaloid. Perubahan susunan asam amino ini akan merubah susunan rantai DNA pada inti sel dan mengakibatkan metabolisme sel terganggu sehingga pertumbuhan bakteri terhambat $^{16}$

Selain alkaloid, senyawa lain yang mempunyai efek antibakteri adalah saponin. Mekanisme kerja saponin sebagai antibakteri yaitu menurunkan tegangan permukaan dinding sel bakteri dan merusak permeabilitas membran. Saponin berdifusi melalui membran luar dan dinding sel yang rentan kemudian mengikat membran sitoplasma sehingga mengganggu kestabilan membran sel. ${ }^{16}$

Senyawa lain yang memiliki efek antibakteri yaitu flavonoid. Flavonoid adalah suatu senyawa fenol yang menunjukkan aktivitas antibakteri. ${ }^{17}$ Mekanisme flavonoid sebagai antibakteri adalah dengan menghambat sintesis dari asam nukleat, menghambat fungsi membran 
sitoplasmik, dan menghambat metabolisme energi bakteri. $^{17,18}$ Flavonoid juga memiliki kemampuan dalam mengganggu aktivitas transpeptidase peptidoglikan sehingga pembentukan dinding sel terganggu. Akibatnya sel tidak dapat menahan tekanan osmotik internal yang mencapai 5 sampai 20 atmosfer. Tekanan ini cukup untuk memecah sel apabila dinding sel dirusak dan pada akhirnya menyebabkan kematian bakteri. ${ }^{16}$

Selain penelitian ini, berbagai penelitian juga telah dilakukan oleh peneliti lain, dan semua penelitian tersebut mempunyai persamaan yang menunjukkan adanya efek bakteriostatis dan bakterisidal dari ekstrak bawang merah terhadap pertumbuhan Streptococcus mutans. Penelitian Jahangirnezhad, Amin, Montazeri dan Eftekhari (2012) di Afrika mengemukakan bahwa ekstrak bawang merah memiliki daya aktivitas antimikroba terhadap pertumbuhan Streptococcus mutans. Pada penelitian ini dilakukan pengujian ekstrak bawang merah terhadap pertumbuhan Streptococcus mutans (PTCC ${ }^{\circledR} 1683^{\mathrm{TM}}$ ) dengan metode dilusi. Hasil penelitian ini menunjukkan bahwa ekstrak bawang merah dapat menghambat pertumbuhan bakteri Streptococccus mutans yaitu 0,4 $\mu \mathrm{g} / \mathrm{ml}$ (KHM) dan membunuh pertumbuhan bakteri Streptococccus mutans yaitu $4,8 \mu \mathrm{g} / \mathrm{ml}$ (KBM). ${ }^{10}$

Dari uraian diatas, dapat dilihat bahwa terdapat perbedaan nilai KHM dan KBM yang didapat pada penelitian ini dengan penelitian lain. Hal ini berarti terdapat perbedaan kemampuan antimikrobial dari ekstrak bawang merah. Adapun hal yang menyebabkan adanya perbedaan kemampuan daya antimikrobial ekstrak bawang merah tersebut adalah umur tanaman, keadaan tanah, curah hujan, dan lingkungan asal tanaman. Bawang merah yang digunakan dalam penelitian ini didapat dari salah satu perkebunan bawang merah di Kecamatan Pangururan Samosir, yang mana berbeda varietasnya dengan bawang merah yang digunakan dalam penelitian sebelumnya. ${ }^{19}$

Ekstrak bawang merah yang digunakan dalam penelitian ini diolah dengan metode perkolasi menggunakan pelarut berupa ethanol 96\%. Dalam teknik ekstraksi perkolasi, filtrat yang telah terbentuk diuapkan dalam vacuum rotary evaporator pada suhu $70^{\circ} \mathrm{C}$. Pada suhu ini, zat-zat antibakteri dalam ekstrak bawang merah terutama yang berupa enzim mungkin telah terdenaturasi sebagian karena pemanasan tersebut. Sehingga efektifitas ekstrak bawang merah sebagai antibakteri berkurang.

Kesimpulan dari penelitian ini adalah terdapat efek daya hambat dan daya bunuh ekstrak bawang merah terhadap pertumbuhan Streptococcus mutans dari karies maupun Streptococcus mutans $\left(\mathrm{ATCC}^{\circledR} 35668^{\mathrm{TM}}\right.$ ) dan tidak terdapat perbedaan efek yang signifikan antara ekstrak bawang merah terhadap pertumbuhan Streptococcus mutans dari karies dan Streptococcus mutans (ATCC $^{\circledR}$ $35668^{\mathrm{TM}}$ ).

\section{DAFTAR PUSTAKA}

1. Pintauli S, Hamada T. Menuju gigi dan mulut sehat : pencegahan dan pemeliharaan. Edisi revisi. Medan : USU Press, 2014 : 4-6.
2. Bidarisugma B, Timur SP, Purnamasari R. Antibodi monoklonal streptococcus mutans 1 (c) $67 \mathrm{kDa}$ sebagai imunisasi pasif dalam alternatif pencegahan karies gigi secara topikal. Berkala Ilmiah Mahasiswa Kedokteran Gigi Indonesia 2012; 1(1): 1-6

3. Badan Penelitian dan Pengembangan Kesehatan Kementerian Kesehata RI. Riset Kesehatan Dasar (RISKESDAS) 2013. Jakarta: 2013: 118-9.

4. Ryan KJ, Ray CG. Medical Microbiology. $4^{\text {th }}$ ed. United States : The McGraw Hill Companies, 2004 : 839 .

5. Prajapati RA, Raol BV. The study on the efficacy of some herbal extracts for the control of dental caries pathogen-streptococcus mutans. International Journal of Pharmaceutical Sciences and Health Care 2014; 4(1): 1-9.

6. Ambarwaty W. Uji daya antibakteri jus bawang merah (Allium ascalonicum L) terhadap pertumbuhan bakteri streptococcus mutans atcc 25175 secara in vitro. Naskah Publikasi Fakultas Kedokteran Gigi Universitas Muhammadiyah 2015; 5(1): 1-6

7. Jaelani. Khasiat Bawang Merah. Yogyakarta: Kanisius, 2007: 16.

8. Fattorusso E, Lorizzi M, Lanzotti V, Scafati OT. Chemical composition of shallot. Journal of Agricultural and Food Chemistry 2002; 50 : 568690.

9. Motlagh HRM, Mostafaie A, Mansouri K. Anticancer and anti-inflammatory activities of shallot extract. Medical Biology Research Center 2010; 7(1): 38-43.

10. Jahangirnezhad M, Amin M, Montazeri EA, Eftekhari Z. In vitro comparison of the effect of shallot extract and chlorhexidine mouthwash on oral pathogens. African Journal of Microbiology Research 2012; 6(6): 1262-4.

11. Mahmoudi R, Zare P, Shadfar S, Ehsani A. Phytochemical and properties of allium ascallonicum essential oil. International Of Microbiology 2011; 2: 237-9.

12. Amin M, Montazeri EA, Mashhadizadeh MA, Sheikh AF. Characterization of shallot an antimicrobial extract of allium ascallonicum. Pak J Med Sci 2009; 25 (6): 948-52.

13. Amin M, Kapadnis BP. Heat stable antimicrobial activity of allium ascalonicum against bacteria and fungi. Indian Journal of Experimental Biology 2005; 43: 1-6.

14. Rattanachaikunsopon P, Phumkhachorn P. Shallot diallyl sulfide content and antimicrobial activity against food-borne pathogenic bacteria. African Journal of Microbiology Research 2009; 3(11): 747-50.

15. Akeel RA, Alseikh Y, Mateen A, Syed R, Janardhan K, Gupta VC. Evaluation of antibacterial activity of crude protein extract from seeds of six different medical plants against 
standard bacterial strais. Saudi Journal of Biological Sciences 2014; 21: 147-50.

16. Rosidah AN, Lestari P, Astuti P. Daya antibakteri ekstrak daun kendali terhadap pertumbuhan streptococcus mutans. Jurnal Pustaka Kesehatan 2014; 2(1): 2, 1-5.

17. Sumono A, Wulan A. Kemampuan air rebusan daun salam (Eugenia polyantha w) dalam menurunkan jumlah koloni bakteri streptococcus sp. Majalah Farmasi Indonesia 2009; 20(3): 112116.
18. Cushine TTP, Lamb AJ. Antimicrobial activity of flavonoids. International Journal of Antimicrobial $2005 ; 26: 343-53$.

19. Wibowo S. Budidaya bawang. Jakarta : Penebar Swadaya, 2000 : 92-131. 